\title{
Does Herpes Simplex Virus Establish Latency in the Eye of the Mouse?
}

\author{
C. M. P. CLAOUÉ ${ }^{1}$ W.A. BLYTH ${ }^{2}$ T. J. HILL ${ }^{2}$, and D. L. EASTY ${ }^{1}$ \\ Bristol
}

\begin{abstract}
Summary
Clinically scarred and neovascularised corneas observed after zosteriform spread of herpes simplex virus (HSV) to the eye of the mouse were found to contain chronic inflammatory cells with a loose retrocorneal membrane. Goblet cells were found in the corneal epithelium.

The trigeminal ganglia of such animals were latently infected with HSV. Whereas HSV was not isolated from eye-washings of diseased eyes, it was isolated from some anterior segments after culture in vitro for up to 13 days. When anterior segments were halved sagittally, HSV could not be isolated from the halves assayed immediately, whereas it was isolated from some of the other halves after organ culture. The possibility of ocular latency is discussed.
\end{abstract}

Herpetic eye disease continues to be a serious cause of corneal morbidity in the western world. ${ }^{1}$ Whilst recent advances in the treatment of epithelial disease (dendritic and geographic ulceration) due to replicating virus ${ }^{2}$ have rendered this aspect of herpetic eye disease easier to manage, chronic stromal disease continues to blind many eyes. The pathogenesis of this condition is not yet fully explained. In particular, the role of the virus in the genesis of disease is poorly understood.

The presence of complete or incomplete viral particles has been documented by electron microscopy in corneal buttons removed at keratoplasty. ${ }^{3-7}$ However, in general HSV was not isolated from such tissue ${ }^{3}$ until cultures of corneal buttons were used. ${ }^{8-11}$

In one of the few long-term experimental studies Openshaw ${ }^{12}$ was able to isolate HSV from cultured whole eyes of mice 5-7 months after corneal inoculation, and claimed that viral antigens were limited to the deeper retinal layers. Similarly, Shimeld et al. ${ }^{13}$ isolated HSV from organ cultures of whole mouse eyes 36 days after anterior chamber inoculation.

We now report investigations on the isolation of HSV from eyes long after the subsidence of primary disease. For this we used the Bristol zosteriform spread model whereby HSV accedes to the eye via neural pathways after inoculation on the snout ${ }^{13-16}$ (and Claoué et al., manuscript submitted). Such spread to the eye via neural pathways is more reminiscent of human recurrent disease than direct corneal inoculation.

\section{Material and Methods}

Mice and Clinical Examinations. Four week old male inbred NIH strain mice bredin the Department of Microbiology, University of Bristol were used. Mice were kept on shredded newspaper to avoid sawdust damage to the eye. Ocular examinations and inoculation were carried out under anaesthesia produced by intraperitoneal injection of pentobar-

From University of Bristol, Departments of Ophthalmology ${ }^{1}$ and Microbiology, ${ }^{2}$ The Medical School, University Walk, Bristol, BS8 1TD.

Correspondence to: Dr. Claoué, Department of Ophthalmology, St. Thomas' Hospital, London, SE1 7EH. Presented at the Annual Congress of the Ophthalmological Society of the United Kingdom, April 1987. 
bitone. Eyes were examined using a Zeiss slit-lamp biomicroscope; animals with abnormal eyes were excluded before inoculation.

Inoculation. The left-hand side of the snout was shaved over an area approximately $6 \mathrm{~mm}^{2}$ and then scarified ten times with a 25 gauge hypodermic needle through a 10 microlitre drop of 199 medium containing $10^{5}$ pfu of HSV1 strain SC16. ${ }^{17}$ Stock virus was titrated on VERO cells and stored at -70 degrees $\mathrm{C}$.

Dissection of eyes and Histology. Since cervical dislocation occasionally caused hyphaemas, eyes were enucleated under deep general anaesthesia and the mice were then immediately killed. All observations were made on the left eye (the side inoculated). For enucleation, the eye was proptosed by tension on the lids and the conjuctiva opened with scissors. If the anterior segment was to be cultured for virus, the instruments used were sterilised by flaming in methylated spirits. Anterior segments were prepared by dissecting around the equator of the eye in a coronal plane. The lens was discarded leaving anterior and posterior segments. For histology, tissue was fixed in 10 per cent formalin and then embedded in paraffin wax: Five micrometre sections were cut for staining with haematoxylin and eosin.

Isolation of Virus. Eye washings were performed by the method previously described. ${ }^{13}$ Tissues (whole eyes and trigeminal ganglia) were excised and freeze-thawed three times with dry ice before grinding in glass grinders in $0.5 \mathrm{ml}$ of 199 medium. At least four 50 microlite aliquots were plated onto VERO cell monolayers ${ }^{17}$ which were incubated for 3 days and examined for viral cytopathic effects.

For organ culture, tissues (see below) were placed in bijoux bottles in $1 \mathrm{ml}$ of 199 culture medium containing 25 per cent FCS and incubated at 37 degrees $\mathrm{C}$ and 5 per cent $\mathrm{CO}_{2}$ in the tissue culture incubator. Samples of the supernatant fluid (100 microlitres) were removed daily for up to 13 days, and placed onto VERO cell monolayers for assay of virus. ${ }^{17}$ The volume of culture medium was maintained by replacement with fresh medium.

\section{Results}

Clinical Disease. One hundred and thirty-four mice were inoculated with $10^{5}$ pfu of HSV. They were examined on days 5-7, and divided into those with normal eyes and lids ('Normaleyed'), and those with a keratouveitis in the left eye ('diseased'). On day 7 there were 75 diseased and 59 normal-eyed mice.

The two groups were re-examined 123 days after inoculation. Only 27 mice remained in the normal-eyed group, a mortality of 54 per cent.
Ten of the mice still had normal eyes, but 17(63 per cent of survivors) now had varying degrees of neovascularisation and scarring of the left cornea. In many cases, a single vascularised corneal facet was seen. Forty-seven mice remained in the diseased group, a mortality of 37 per cent. All left eyes were still abnormal. Nine eyes were phthysical; these were not used for experimental purposes. The remaining eyes ( 80 per cent of surviving animals) showed marked corneal vascularisation with varying degrees of opacification. In most cases, the iris could not be seen. Single vascularised facets were never seen in this group.

For later experiments animals with similarly diseased eyes were produced by inoculation on the snout with $10^{5} \mathrm{pfu}$.

Histology. Five left eyes from mice inoculated 120 days previously were examined histologically. All showed a similar appearance, with a slightly atrophic anterior uvea and a loose-knit retrocorneal membrane in which were found macrophages containing what appeared to be haemosiderin. The cornea showed extensive vascularisation of the stroma, with an infiltrate of a mixture of mononuclear and polymorphonuclear cells throughout. Goblet cells were present in the corneal epithelium.

Isolation of HSV from the Eye. The eyes of 54 mice inoculated 140 days previously were ground and tested for HSV; no virus was isolated.

The left eyes of 8 mice were washed 123 days after inoculation. None of the washings yielded virus. Immediately after washing, eyes were removed and the anterior segments were placed in culture. Four of the eight yielded HSV after a mean of 7.7 days.

The left eyes were enucleated from 14 mice 227-271 days after inoculation. The anterior segment was dissected free and then divided into two sagittally. One half of each was put into organ culture, and the other half was ground and assayed for infectious virus. No HSV was isolated from the ground tissues, but HSV was isolated from one cultured half anterior segment on day 8 .

The left trigeminal ganglia were excised from the same 14 mice. They were divided into halves, one of which was immediately ground and assayed for infectious virus and the other 
was put into organ culture. HSV was not isolated from any of the ground tissues. In contrast, 12 (86 per cent) of the cultures shed HSV into the supernatant after a mean of 6.4 days in culture.

The left eyes were enucleated from 10 mice 180-368 days after inoculation, and the anterior segments dissected free. They were then divided sagittally into halves and both were put separately into organ culture. HSV was isolated from 3 specimens, from the two halves of the same eye (on days 6 and 9) and from a further specimen on day 6 .

The anterior segments, posterior segments, and upper lids from the left eyes of 12 mice inoculated 286 days previously were placed separately in organ culture. HSV was isolated from only 1 posterior segment (after 17 days in culture), whereas virus was isolated from 4 of the anterior segments from the same eyes. None of the cultures of upper lid yielded HSV. The posterior segment which shed HSV came from an eye where the anterior segment also shed HSV. Histological examination of the posterior segment which had shed HSV showed only unrecognisable tissue, whereas other samples which had not shed virus showed recognisable retinal architecture.

\section{Discussion}

The corneal scarring and neovascularisation seen in the 'diseased' group of mice was reminiscent of that seen in chronic stromal keratitis due to HSV in humans. ${ }^{18}$ It appears that after the acute keratouveitis which follows zosteriform spread of inection, ${ }^{14.15},{ }^{19}$ the eyes of experimental animals never return to normal. In those animals which did not show ocular disease during the acute infection, a large proportion of eyes showed abnormalities of the cornea when examined 123 days after inoculation. Such abnormalities include vascularised corneal facets reminiscent of a healed dendritic ulcer. However, it is not known whether these abnormalities were associated with spontaneous episodes of herpetic keratitis or other causes. Animals in the normal eyed group were nearly all latently infected in the ophthalmic division of the trigeminal ganglion (Claoué et al., manuscript in preparation). Therefore, these late abnormalities may well have arisen from episodes of spontaneous recurrent disease such as occur in the rabbit. ${ }^{20}$

The histological appearance of diseased eyes was what might be expected after a severe keratouveitis. The presence of haemosiderinladen macrophages is the likely legacy of previous hyphaemas. ${ }^{14}$ The presence of goblet cells in the corneal epithelium suggests that following acute keratitis in the mouse, healing is by repopulation with conjunctival cells.

As in the human during chronic herpetic eye disease, ${ }^{21-23}$ a chronic inflammatory response was found in the cornea. The presence of a retrocorneal membrane was probably a consequence of the severity of the uveal involvement in the acute disease. A granulomatous reaction to Descemet's membrane is a characteristic but rare histological feature of human herpetic stromal keratitis, ${ }^{24}$ but was not observed in the mouse.

The absence of HSV in ground trigeminal ganglia and its isolation from cultured ganglia indicates that the methods that we have used were satisfactory for demonstrating virus in a tissue where $\mathrm{HSV}$ is accepted to be latent. ${ }^{25} \mathrm{We}$ therefore used the same techniques to investigate whether HSV was present in ocular tissue at late times after inoculation.

The isolation of HSV from anterior segments in organ culture did not appear to be from an infected external ocular surface, since eye-washings taken immediately before culture failed to yield virus. In addition, culture of lid tissue did not yield HSV, excluding this as a site of chronic replicative infection which might have contaminated the anterior segment before culture. Furthermore, our failure to isolate HSV from ground ocular tissue militates against chronic replicative infection in the eye. Thus the absence of infectious virus from anterior segments before culture, and its isolation after a mean of 7.7 days in culture (a time longer than for trigeminal ganglia where latency is accepted) suggests that the virus may be latent in the eye.

We were unable to repeat the findings of Openshaw, ${ }^{12}$ since we isolated HSV far more frequently from anterior segments than from posterior segments. Furthermore, in the one case where HSV was isolated from posterior segment tissue, we cannot exclude con- 
tamination with tissue from the anterior segment.

Preliminary immunohistochemical examination of cultured anterior segments which yielded HSV suggests that virus is predominantly present in the anterior uveal tissue (Claoué et al., manuscript in preparation). This shows an interesting similarity with the acute infection, where HSV replicates predominantly in the uveal tissue. ${ }^{14}$

Whilst HSV is widely considered to establish latency only in neural tissue, evidence for extraneural latency in animals in skin and footpad tissue has been presented (reviewed by Hill). ${ }^{25}$ The isolation of HSV from anterior segments of diseased mouse eyes after culture is reminiscent of the results of other workers ${ }^{8-11}$ with human corneal buttons removed at the time of penetrating keratoplasty for stromal herpetickeratitis. If, as theseobservationssuggest, $\mathrm{HSV}$ is able to establish a latent infection in ocular tissues, the infection may reactivate as happens in ganglia. In the eye, such reactivation could be involved in the initiation and perpetuation of chronic herpetic eye disease.

This work was made possibly by a grant from the Wellcome Trust. We would like to thank Mrs. Carolyn Shimeld for sharing her technical expertise, Mr. Tim Hodges for dedicated technical assistance, and Miss K. E. Stevenson, FRCS for helpful discussions.

\section{References}

${ }^{1}$ Tullo AB: Herpes simplex keratitis: latent and recurrent infection. In Easty DL and Smolin G, eds. External Eye Disease, London: Butterworths 1985; 133-153.

2 O'Day DM and Jones BR: Herpes simplex keratitis. In Duane TD and Jaeger EA, eds. Clinical Ophthalmology, Vol. 4, Cambridge: Harper and Row 1985; 1-20.

${ }^{3}$ Dawson C, Togni B, Moore TE: Structural changes in chronic herpetic keratitis. Arch Ophthalmol 1968, 79: 740-7.

${ }^{4}$ Metcalf JF and Kaufman HE: Herpetic stromal keratitis-evidence for cell-mediated immunopathogenesis. Am J Ophthalmol 1976, 82: 827-34.

${ }^{5}$ Jones BR, Falcon MG, Williams HP, Coster DJ: Symposium on Herpes Simplex Eye Disease: Objectives of Therapy of Herpetic Eye Disease. Trans Ophthalmol Soc UK 1977, 97: 305-13.

${ }^{6}$ Meyers-Elliott RH, Pettit TH, Maxwell A: Viral antigens in the immune ring of herpes simplex stromal keratitis. Arch Ophthalmol 1980, 98: 897-904.

${ }^{7}$ Ahonen R, Vannas A, Makitie J: Virus particles and leukocytes in herpes simplex keratitis. Cornea 1984, 3: 43-50.
${ }^{8}$ Shimeld C, Tullo AB, Easty DL, Thomsitt J: Isolation of herpes simplex virus from the cornea in chronic stromal keratitis. Br J Ophthalmol 1982, 66: 643-7.

${ }^{9}$ Tullo AB, Easty DL, Shimeld C, Stirling PE, Darville JM: Isolation of herpes simplex virus from corneal discs of patients with chronic stromal keratitis. Trans Ophthalmol Soc UK 1985, 104: 159-65.

${ }^{10}$ Coupes D, Klapper PE, Cleator GM, Bailey AS, Tullo AB: Herpesvirus simplex in chronic human stromal keratitis. Curr Eye Res 1986, 5: 735-8.

${ }^{11}$ Cook SD, Aitken DA, Loeffler KU, Brown SM: Herpes simplex virus in the cornea: an ultrastructural study on viral reactivation. Trans Ophthalmol Soc UK 1986, 105: 634-41.

12 Openshaw $\mathrm{H}$ : Latency of herpes simplex virus in ocular tissue of mice. Infection and Immunity 1983, 39: 960-2.

${ }^{13}$ Shimeld C, Lewkowicz-Moss SJ, Lipworth KM, Hill TJ, Blyth WA, Easty DL: Antigens of herpes simplex virus in whole corneal epithelial sheets from mice. Arch Ophthalmol 1986, 104: 1830-4.

${ }^{14}$ Claoué CMP, Hodges TJ, Hill TJ, Blyth WA, Easty DL: The Histology of the Eye after Zosteriform Spread of Herpes Simplex virus in the Mouse. BrJ Exp Path (in press).

${ }^{15}$ Claoué CMP: A New Look at Experimental Herpes Simplex Eye Disease; Preliminary Results of Clinical Disease in the NIH Mouse after Zosteriform Spread. Trans Ophthalmol Soc UK 1986, 105: 401-3.

${ }^{16}$ Tullo AB: Mechanisms of Latent and Recurrent Ocular Infection with Herpes Simplex Virus. MD Thesis, University of Bristol, 1982.

${ }^{17}$ Hill TJ, Field HJ, Blyth WA: Acute and recurrent infection with herpes simplex virus in the mouse: A model for studying latency and recurrent disease. J Gen Virol 1975, 28: 341-53.

${ }^{18}$ Easty DL: Viral Disease of the Eye, London, LloydLuke, 1985.

${ }^{19}$ Claoué CMP. Hill TJ, Blyth WA, Easty DL: Clinical Findings after Zosteriform Spread of Herpes Simplex Virus to the Eye of the Mouse. Curr Eye Res 1987. 6: 281-6.

20 Sery TW: Random Occurrence of Herpetic Disciform Keratitis in Rabbits. Am J Ophthalmol 1959, 48: 57-71.

${ }^{21}$ Kimura SJ: Herpes simplex uveitis: a clinical and experimental study. Trans Am Ophthalmol Soc 1962, 60: 440-70.

22 Hogan MJ, Kimura SJ, Thygeson P: Pathology of herpes simplex kerato-iritis. Am J Ophthalmol 1964, 57: 551-64.

${ }^{23}$ Teitelbaum CS, Streelen BW, Dawson CR: Histopathology of herpes simplex keratouveitis. Invest Ophthalmol Vis Sci 1986, 27: (3), ARVO supplement $\mathrm{p} 47$.

${ }^{24}$ Weiner JM, Carroll N, Robertson IF: The Granulomatous reaction in herpetic stromal keratitis: immunohistochemical and ultrastructural findings. A us and NZ J Ophthalmol 1985, 13: 365-72.

${ }^{25}$ Hill TJ: Herpes simplex virus latency. In B Roizman, ed. The Herpesviruses Vol 3, London, Plenum Press, 1985, 175-240. 